\title{
Pengaruh Pendidikan Dan Pelatihan Terhadap Kinerja Melalui Kompetensi Bidan: Studi Kuantitatif
}

\section{The Effect of Education and Training on Performance Through Midwife Competence: Quantitative Study}

\author{
Azmin Said Telaumbanua( ${ }^{\left(1^{*}\right)}$ \& Yeni Absah(2) \\ ${ }_{1}^{1}$ Program Pascasarjana, Universitas Terbuka, Indonesia \\ 2Program Studi Manajemen, Universitas Sumatera Utara, Indonesia \\ Disubmit: 23 April 2021; Diproses: 25 April 2021; Diaccept: 28 Juli 2021; Dipublish: 02 Agustus 2021 \\ *Corresponding author: E-mail: azmins85.as@gmail.com
}

\begin{abstract}
Abstrak
Kinerja individu sangat mempengaruhi hasil dalam sebuah tugas yang kerjakan. Namun untuk mendapatkan hasil yang maksimal maka diperlukan pencapaian kompetensi yang baik melalui keikutsertaan dalam program pendidikan dan pelatihan/diklat. Kompetensi yang rendah diduga dipengaruhi oleh pendidikan dan pelatihan/diklat yang kurang efektif, salah satunya disebabkan karena kurangnya pelaksanaan kegiatan Diklat itu sendiri. Tujuan umum dalam penelitian ini adalah untuk mengetahui pengaruh pendidikan dan pelatihan/diklat terhadap kinerja melalui kompetensi bidan di UPTD Puskesmas Kecamatan Gunungsitoli.Penelitian ini termasuk penelitian kuantitatif dengan metode kausalitas yang tujuan untuk melihat sebab akibat antara variable dan desain yang digunakan adalah cross sectional. Adapun populasi dalam penelitian ini adalah seluruh bidan di wilayah kerja UPTD Puskesmas Kecamatan Gunungsitoli berjumlah 96 orang dan teknik pengambilan sampel menggunakan purposive sampling dimana pemilihan sampel berdasarkan kriteria yang ditentukan oleh peneliti yaitu bidan ASN yang pernah mengikuti pendidikan dan pelatihan/diklat berjumlah 55 orang. Instrumen dalam penelitian ini menggunakan kuesioner yang telah dilakukan uji validasi dan hasil dari pengumpulan data penelitian di analisis menggunakan uji analisis path. Sesuai dengan hasil uji yang didapatkan nilai P-value yaitu 0,000 yang artinya lebih kecil dari 0,05. Dari hasil uji tersebut, maka dapat disimpulkan bahwa pendidikan dan pelatihan sangat berpengaruh terhadap kinerja, dimana bidan yang sudah mengikuti pendidikan dan pelatihan memiliki kinerja yang baik daripada bidan yang belum mengikuti pendidikan dan pelatihan dilihat dari segi manajemen dan pelayanan. Dalam penelitian ini kompetensi berpengaruh besar dalam penilaian kinerja, dimana kompetensi digunakan sebagai alat ukur yang dapat menentukan baik tidaknya suatu kinerja. Hal ini juga terjawab dari hasil penelitian dimana nilai kompetensi dengan P-value 0,000 yang artinya lebih kecil dari 0,05. Dari hasil tersebut dapat diketahui bahwa bidan yang memiliki kompetensi memiliki kinerja yang baik dan sebaliknya jika bidan tidak memiliki kompetensi maka kinerjanya kurang baik. Dari Hasil penelitian yang sudah dilakukan maka dapat disimpulkan adanya pengaruh pendidikan dan pelatihan/diklat terhadap kinerja melalui kompetensi bidan. Untuk selanjutnya hasil penelitian ini dapat menjadi dasar bagi puskesmas dalam mengembangkan kompetensi dan kinerja staf dan pegawai yang bekerja di wilayah kerja UPTD Puskesmas Kecamatan Gunungsitoli baik bidan ASN maupun bidan tenaga sukarela dengan tujuan adanya peningkatan mutu dan kinerja.
\end{abstract}

Kata Kunci: Pendidikan; Pelatihan; Kompetensi; Kinerja

\begin{abstract}
Individual performance greatly affects results in a task being performed. However, to get maximum results, it is necessary to achieve good competence through participation in education and training programs. Low competence is thought to be influenced by ineffective education and training, one of which is due to the lack of implementation of training activities itself. The purpose of this research is to determine the influence of education and training on performance through the competence of midwives at UPTD health center Gunungsitoli. This research is a quantitative research with cross sectional design. The population in this study is all midwives in the working area of the UPTD health center Gunungsitoli
\end{abstract}


totaling 96 people and the sampling technique used was purposive sampling. The selection of this sample was based on the criteria determined by the researcher, namely the ASN (State Civil Apparatus) midwives who have attended education and training totaling 55 people. The instrument in this study used questionnaires that have been tested for validation and the results of the research data collection were analyzed using the path analysis test. In accordance with the test results, the P-value is 0,000, which means smaller than 0.05. From the results of these tests, it can be concluded that education and training greatly influence performance, where midwives who have attended education and training have better performance than midwives who have not attended education and training in terms of management and service. In this study, competence has a big influence in performance assessment, where competence is used as a measuring tool that can determine whether a performance is good or not. This is also answered by the results of the study where the competency value with a P-value 0,000, which means smaller than 0.05. Based on the result, it can be concluded that midwives who have competence have good performance and vise versa if the midwives do not have competence then the performance is not good. From the results of the research that has been done, it can be concluded that there is an influence of education and training on performance through the competence of midwives. Henceforth, the results of this study can be the basis for the health center in developing the competence and performance of staff and employees who work in the work area of the UPTD health center Gunungsitoli, both ASN midwives and volunteer midwives with the aim of improving quality and performance.

Keywords: Education; Training; Competence; Performance.

DOI: https://doi.org/10.51849/j-p3k.v2i2.103

Rekomendasi mensitasi :

Telaumbanua, A.S. \& Absah, Y. (2021), Pengaruh Pendidikan Dan Pelatihan Terhadap Kinerja Melalui Kompetensi Bidan: Studi Kuantitatif. Jurnal Penelitian Pendidikan, Psikologi dan Kesehatan (J-P3K), 2 (2): 142147. 


\section{PENDAHULUAN}

$\begin{array}{clr}\text { Kinerja } & \text { individu } & \text { sangat } \\ \text { mempengaruhi } & \text { keberadaan } & \text { suatu } \\ \text { organisasi atau } & \text { perusahaan. } & \text { Apabila }\end{array}$ kinerja individu baik maka perkembangan organisasi atau perusahaan juga akan baik. Menciptakan kinerja yang baik tentu bukan hal yang mudah, dalam hal ini dibutuhkan perhatian pimpinan dalam mengawasinya. Pimpinan juga menjadi panutan bagi karyawan dalam hal melaksanakan pekerjaan, kedisiplinan dan berpengaruh dalam memotivasi karyawan dalam bekerja. Dengan demikian atasan dapat memberi teguran ataupun sanksi bagi karyawan yang melanggar peraturan yang telah diberikan (Fathoni, 2007).

Bidan dalam melaksanakan pelayanan kesehatan berperan sebagai pemberi Pelayanan Kebidanan, pengelola Pelayanan Kebidanan, penyuluh dan konselor bagi K1ien, pendidik, pembimbing, dan fasilitator klinik, penggerak peran serta masyarakat dan pemberdayaan perempuan, serta peneliti. Pelayanan Kebidanan yang diberikan oleh Bidan didasarkan pada pengetahuan dan kompetensi di bidang ilmu Kebidanan yang dikembangkan sesuai dengan kebutuhan Klien (UU Kebidanan, 2019).

Untuk dapat menilai/mengukur penguasaan kompetensi standar, kepada setiap tenaga bidan perlu dilakukan uji kompetensi, sebagai bukti bahwa bidan memiliki kompetensi yang telah di tetapkan untuk dapat melakukan praktik profesi kebidanan setelah dinyatakan lulus uji kompetensi setiap bidan akan mendapatkan sertifikat Uji Kompetensi. Bidan yang telah memiliki sertifikat uji kompetensi (Sertified Midwife). Bagi bidan yang telah memiliki sertifikat uji kompetensi dan teregistrasi maka yang bersangkutan mempunyai hak untuk mendapatkan ijin praktik (baik untuk perorangan maupun kelompok) dari pemerintah (IBI, 2017).

\section{METODE PENELITIAN}

Pada penelitian ini menggunakan metode kausalitas dimana metode ini menjelaskan sebab akibat antara beberapa variable sehingga dapat ditarik kesimpulan. Adapun Desain penelitian ini menggunakan desain cross sectional dimana pengukuran dilakukan secara bersamaan dalam satu waktu.

Penelitian Pengaruh Pendidikan Dan Pelatihan Terhadap Kinerja Melalui Kompetensi Bidan Pada UPTD Puskesmas Kecamatan Gunungsitoli ini dilakukan di UPTD Puskesmas Kecamatan Gunungsitoli yang dilaksanakan pada bulan September 2020 sampai dengan Januari 2021.

Dalam penelitian ini kriteria sampel yang digunakan adalah bidan yang telah mengikuti pelatihan yang berjumlah 55 (lima puluh lima) orang, dengan kriteria sampel antara lain merupakan ASN di UPTD Puskesmas Kecamatan Gunungsitoli, berprofesi sebagai bidan, telah mengikuti pendidikan dan pelatihan/diklat, bersedia menjadi responden dengan instrument menggunakan kuesioner yang telah dilakukan uji validitas dan reabilitas, Lokasi penelitian ini berada di Kota Gunungsitoli yang mana terletak di Provinsi Sumatera Utara dengan letak geografis berada di kepulauan Nias.

Penelitian ini dilakukan dengan cara mengumpulkan data-data, dan menganalisis dengan teknik analisis deskriptif dan path analysis atau analisis 
jalur, sehingga memberikan suatu gambaran tentang suatu keadaan secara objektif berdasarkan teori yang sudah ada. Sedangkan sifat penelitian ini adalah menguraikan dan menjelaskan tentang kedudukan satu variabel serta hubungannya dengan variabel yang lain.

\section{HASIL DAN PEMBAHASAN}

Berdasarkan hasil yang telah didapatkan dari penelitian bahwa bidan yang telah mengikuti pelatihan dan pendidikan/diklat memiliki komptensi dalam menjalankan tugas-tugas yang dibebankan kepadanya dengan baik. Setiap pekerjaan yang dilakukan sesuai dengan indicator yang diinginkan dalam ruang lingkup kerja masing-masing. Bidan yang telah mengikuti diklat memahasi porsi kerja dan kewajiban yang harus dilakukan dengan aturan-aturan yang menjadi batas dalam melakukan tugas dan fungsinya.

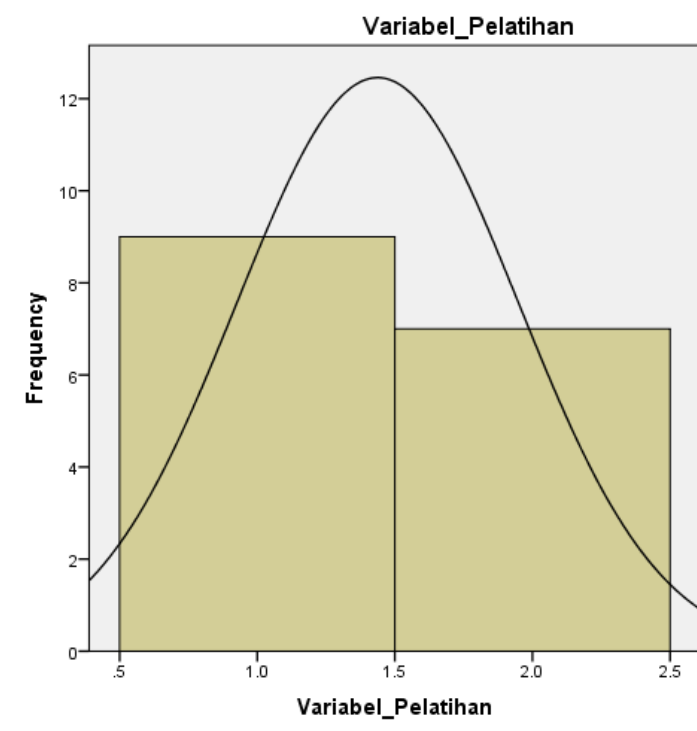

Gambar 1. Variabel Pendidikan dan Pelatihan/Diklat puskesmas. Dalam penelitian yang telah dilakukan didapatkan bahwa terdapat pengaruh positif atau memiliki pengaruh yang sangat signifikan natara kompetensi terhadap kinerja. Dimana setiap bidan yang memiliki kompetensi yang baik sesuai standar yang telah dibuat oleh organisasi Ikatan Bidan Indonesia (IBI) mampu meningkatkan soft skill dan hard skill bagi setiap individu.

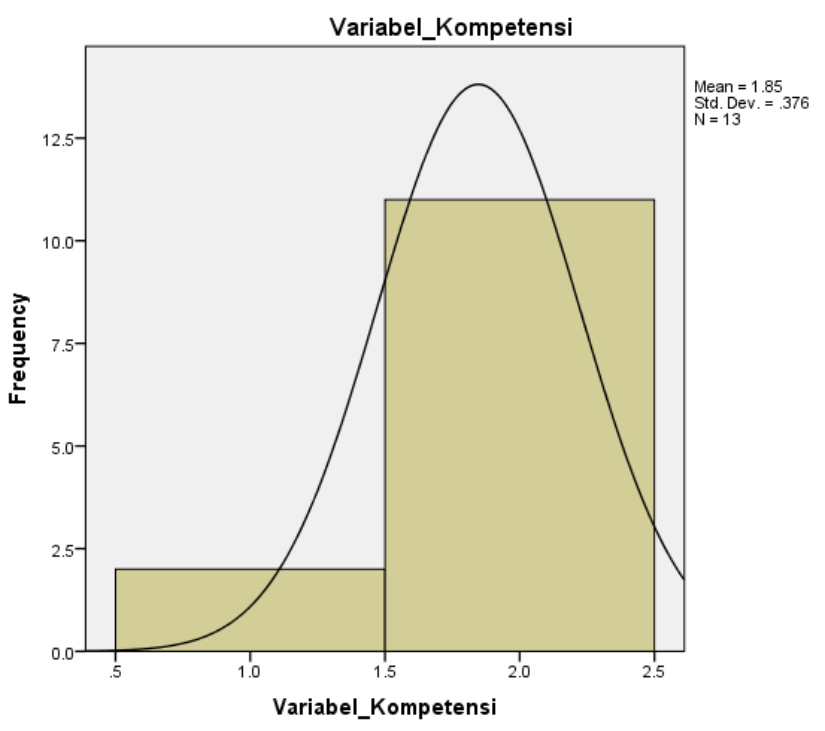

Gambar 2. Variabel Kompetensi Kinerja

Berdasarkan hasil yang telah didapatkan dari penelitian bahwa bidan yang telah mengikuti pelatihan dan pendidikan/diklat memiliki kinerja dalam menjalankan tugas-tugas yang dibebankan kepadanya dengan baik. Setiap pekerjaan yang dilakukan sesuai dengan indicator yang diinginkan dalam ruang lingkup kerja masing-masing. Bidan yang telah mengikuti diklat memahasi porsi kerja dan kewajiban yang harus dilakukan dengan aturan-aturan yang menjadi batas dalam melakukan tugas dan fungsinya.

\footnotetext{
Fungsi Kompetensi dangat mempengaruhi kinerja bidan dalam menjalankan tugasnya di sebuah
} 


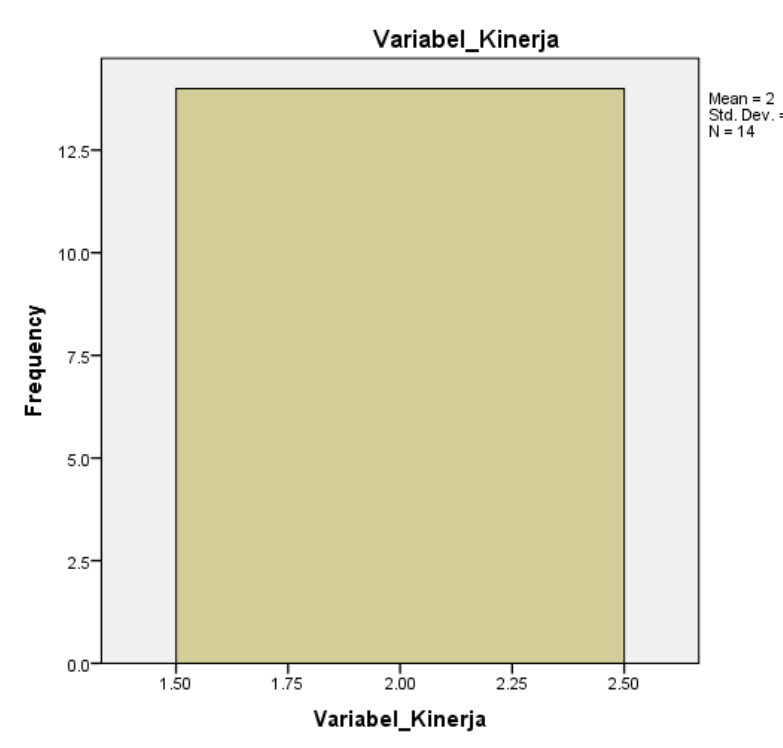

Gambar 3. Variabel Kinerja

Tabel 1. Pengaruh Pendidkan dan Pelatihan/Diklat Terhadap Kinerja melalui Kompetensi ANOVAa

$\begin{array}{lllll}\text { Model } & \begin{array}{l}\text { Sum ofdf } \\ \text { Squares }\end{array} & \begin{array}{l}\text { Mean } \\ \text { Square }\end{array} & \text { F } & \text { Sig. }\end{array}$

\begin{tabular}{lllll}
\hline & Regressi 95.418 & 2 & 47.709 & $13.760 .000 \mathrm{~b}$ \\
1 & on & & & \\
Residual 180.292 & 52 & 3.467 & \\
& Total 275.709 & 54 & & \\
\hline
\end{tabular}

Hasil penelitian menunjukkan bahwa terdapat pengaruh yang positif dan signifikan antara variabel pelatihan terhadap kinerja melalui kompetensi bidan di UPTD Puskesmas Gunungsitoli, Hal itu dibuktikan hasil uji Analisa Path didapatkan nilai $\mathrm{F}$ hitung sebesar 13.760 dengan tingkat signifikan (Sig.) sebesar 0.000 . Jadi $F_{\text {hitung }}>F_{\text {tabel }}(13.760>3,16)$ atau signifikansi $(0.000<0.05)$ artinya bahwa variabel pelatihan terhadap kinerja melalui kompetensi memiliki pengaruh yang positif.

Pengaruh pelatihan dan pendidikan/diklat terhadap kinerja di UPTD Puskesmas Gunungsitoli sangat memiliki pengaruh yang sangat positif melalui kompetensi yang dimiliki oleh bidan sehingga kinerja selama melakukan tugas memberikan hasil yang baik. Dari hasil penelitian yang dilakukan bahwa pengaruh antara variable sangat bernilai positif dengan nilai signifikan 0,000.

Penelitian ini juga didukung oleh penelitian yang dilakukan oleh Purnomo (2016) yang menyatakan bahwa, pendidikan dan pelatihan berpengaruh secara tidak langsung terhadap kinerja melalui kompetensi. Kompetensi adalah kemampuan dan kemauan untuk melakukan sebuah tugas dengan kinerja yang efektif. Semakin baik pendidikan dan pelatihan yang diterima oleh karyawan maka akan semakin meningkat pula kompetensi yang dimiliki dan akan semakin meningkat pula kinerja yang akan ditunjukkan oleh karyawan.

Kinerja merupakan kapasitas individu untuk mengerjakan tugas dalam pekerjaannya. Kemampuan kerja yang maksimal akan meningkatkan nilai SDM yang dipekerjakan oleh organisasi atau lembaga yang bersangkutan. Masalah kinerja tidak dapat dipisahkan oleh kemampuan kerja karyawan dalam melakanakan tugas. Mangkunegara (2016) menyatakan faktor yang mempengaruhi pencapaian kinerja adalah faktor kemampuan (abIility) yang terdiri dari pengetahuan (knowledge) dan keterampilan (skill). Organisasi memerlukan SDM yang memiliki kemampuan kerja yang sesuai dengan kebutuhan dalam organisasi untuk meningkatkan kinerja karyawan. Melalui peningkatan kemampuan kerja maka kinerja karyawan dapat meningkat.

\section{SIMPULAN}

Dari hasil penelitian yang telah ditemukan bahwa adanya pengaruh pendidikan dan pelatihan/diklat terhadap kinerja melalui kompetensi bidan. Profesi 
bidan mampu menjalankan tugas dan kinerjanya dengan maksimal apabila masing-masing memiliki kompetensi yang mencukupi dengan mengikuti pendidikan dan pelatihan/diklat dan juga adanya surat tanda registrasi yang dikeluarkan oleh pemerintah sebagai bukti yang sah sehingga segala tindakan yang dilakukan sesuai dengan latar belakang pendidikan serta memiliki dasar hukum yang dilindungi oleh undang-undang.

\section{DAFTAR PUSTAKA}

Abdurrahman, Fatoni. (2017). Organisasi dan Manajemen Sumber Daya Manusia. Jakarta: Rineka Cipta.

Fathoni, A. (2007). Manajemen Sumber daya Manusia. Rineka Cipta.

IBI. (2017). Ikatan Bidan Indonesia. www.ibi.or.id Purnomo, D., Sudana, I. P., \& Sasrawan Mananda, I. G. (2016). Pengaruh Pendidikan Dan Pelatihan Terhadap Kompetensi Serta Dampaknya Pada Kine Pramuwisata Bali. Jurnal IPTA.

Ikatan Bidan Indonesia. (2017). WWW.ibi.or.id

Undang Undang Kebidanan Tahun 2019

Purnomo, D., Sudana, I. P., \& Sasrawan Mananda, I. G. (2016). Pengaruh Pendidikan Dan Pelatihan Terhadap Kompetensi Serta Dampaknya Pada Kine Pramuwisata Bali. Jurnal IPTA,4(2),51.

Mangkuprawira, Sjafri. (2011). Manajemen Sumber Daya Manusia Strategi. Ghalia Indonesia 